\title{
Contribution to the Historyof Serbian Medicine: Ten Years from the Introduction of Clostridium Difficile into Microbiological Diagnostics in Serbia
}

\author{
Predrag Stojanović1,2, Branislava Kocić1,2, Gorana Dragovac ${ }^{3,4}$, Marina Randjelović2 \\ Vukica Pantović2 ${ }^{2}$ Zorica Mitić ${ }^{,}$Kristina Stojanović ${ }^{6}$ \\ ${ }^{1}$ University of Niš, Faculty of Medicine, Niš, Serbia \\ ${ }^{2}$ Public Health Institute Niš, Niš, Serbia \\ ${ }^{3}$ University of Novi Sad, Faculty of Medicine, Novi Sad, Serbia \\ ${ }^{4}$ Institute of Public Health of Vojodina, Novi Sad, Serbia \\ Institute of Public Health Požarevac, Požarevac, Serbia \\ 6"Zona Vida" Ophthalmology Clinic, Niš, Serbia
}

\section{SUMMARY}

In Serbia, the first isolates of $C$. difficile were isolated in the Public Health Institute (PHI), Center for Microbiology in Niš, at the end of 2005.

The National Reference Laboratory for Anaerobic Infections (NRLA) in PHI Niš confirmed the toxigenic strains that caused the first three registered hospital epidemics in Serbia, in 2006 at the Clinic of Neurology, Clinical Center Niš, in 2007 at the Clinical Center of Vojvodina in Novi Sad, and in 2009 in the General Hospital in Požarevac.

In 2014, $C$. difficile species were isolated for the first time from 175 environment samples in the research studies which were conducted in NRLA of PHI Niš. In the samples of soil taken from the ground within the Clinical Center Niš, those taken from the parks at the territory of the Municipality of Nišs, samples of mud and sand around the illegal sewage systems at the territory of the Municipality of Niška Banja, a small number of bacteria $C$. difficile producing the toxins $(A+B+)$ as well as non-toxigenic isolates (A-B-) were found.

Results of the first epidemiological investigations of cases of diarrhea associated with prior antibiotic treatment applied in hospitalized patients in a number of health centers in our country, microbiological investigations done in the Public Health Institute, valuable discussions at professional and scientific meetings influenced the general attitude that isolation and identification of $C$. difficile and/or detection of toxin produced by this bacteria should be part of the routine work in the Serbian microbiological laboratories.

Key words: C. difficile, Serbia, environment samples 


\section{INTRODUCTION}

Clostridium (C.) difficile is a typical representative species of the genus Clostridium, which includes a group of Gram-positive, motile, aerotolerant or anaerobic bacilli, widespread in the soil and intestinal tract of animals. They usually form subterminal spores, rarely central. The spores are resistant to heat, drying and chemical agents which allows them to survive in adverse environmental conditions. Electron microscopy can provide visualization of flagella and other bumps on the bacterial cell (1).

Although the written records about pseudomembranous colitis (PMC) exist since 1893, C. difficile was first described in 1935, by Hall and Toole. These researchers were the first who succeeded to isolate Gram-positive anaerobic sporogenic bacilli from the stool of the newborn child. The first term - Bacillus difficilis was given due to slow growth and very heavy subcultivation of cultures obtained from patient material (2). Later, it was classified in the genus Clostridium. It was considered non-pathogenic as was most commonly cultured from the samples of healthy children. However, during the fifties of the last century it was discovered that $C$. difficile culture filtrate probably contained a toxic product which upon parenteral inoculation may have caused death of laboratory animals. During the 60's and 70's of the last century, massive use of broad-spectrum antibiotics was started. In addition, an increase in the incidence of colitis and PMC in patients with positive $C$. difficile findings in stool samples was recorded. It was also noticed that the stool filtrate in these patients had a cytotoxic effect on cell culture. Studies conducted during 1997 pointed out that prolon-ged antibiotic therapy can influence lethal $C$. difficile colitis. Moreover, these researches determined that the production of toxins is responsible for the occurrence of the disease (3). Further researches have shown that these bacterial species can produce two toxins ( $\mathrm{A}$ and $\mathrm{B}$ ) that are responsible for causing the disease(Clostridium difficile-associated disease (CDAD)).

In the last thirty years, a lot of studies with the goal to establish the presence of this microorganism in the environment and possible sources of infection have been done. The first comprehensive study was conducted by Hafiz and associates in 1974, who isolated this bacterial type from soil, sand, silt shallow river, hay, excrement of camels, donkeys, cows and horses in Pakistan (4). Earlier, the researchers had also found this bacterial species in the soil, but only in that which was territorially related to waste materials of patients who had diarrhea (5). Subsequent studies had confirmed the presence of $C$. difficile in environmental samples with increased moisture content (6). The results of the above mentioned researches indicate uneven distribution of $C$. difficile in the environment, but these findings may be the result of different sampling methodology. Further research on the man's environment as a source of infection was carried out by $\mathrm{Al}$ Saif and Brazier (7) in 1996 who examined 2,580 environmental samples from the territory of Cardiff South Wales region-the United Kingdom. Samples were screened by methodology that allowed the maximum germination of spores. The results showed that $7.1 \%$ of the samples were positive for C. difficile, and out of that $21 \%$ from soil, $7 \%$ from pets and $20 \%$ from the samples of hospital environment. Additionally, in the samples of water from rivers and lakes with the high prevalence of $87.5 \%$ and $46.5 \%$, respectively, bacteria $C$. difficile were proved.

Besides, $50 \%$ of the samples of pool water were positive for $C$. difficile, as well as $2.4 \%$ of the samples of fresh plants and $2.2 \%$ of the samples of the surfaces of private houses and apartments. Data from these studies have shown that the general population is exposed to $C$. difficile and they might bring it into the hospital.

\section{Microbiological diagnosis of CDAD in Serbia}

At the beginning of 2005, based on the data on diarrheal syndrome with unclear infection etiology, it was concluded that one of the priorities in our country was establishing the microbiological diagnosis of CDAD (8-10).

In Serbia, the first isolates of C. difficile were obtained in the Public Health Institute (PHI), Center for Microbiology in Niš, at the end of 2005 (11). The first epidemic isolate with the positive toxin test was found in a stool sample of a hospitalized patient (male, 46 years old) in the Clinical Center Niš (Clinic of Neurology) (1, 12). In the National Referent Laboratory for Anaerobic Infections in the PHI Niš, toxigenic strains of pathogens which caused the second and third hospital outbreaks in Serbia were confirmed, in the Clinical Center in Novi Sad in 2007 and in the General Hospital in Požarevac in 2009 (1).

The epidemic in the Clinic of Neurology in Niš in 2006 included 4 patients placed in the intensive care units. The patients were aged between 44 and 72 years (75\% were males). The epidemic lasted 35 days. $C$. difficile and its toxins $(\mathrm{A}+\mathrm{B}+)$ were found in stools of all the patients. All of them had severe predisposing internal and neurological diseases as well as multiple high risk factors for the occurrence of infections caused by $C$. difficile (severe primary disease, multiple previous hospitalizations, the use of two or more antibiotics, administration of laxatives and intestinal application of 
invasive endoscopic methods during the previous two months, etc.) $(1,9)$.

The epidemic of diarrhea caused by $C$. difficile in the hospital of Novi Sad was observed in 4 patients from the clinics of internal medicine whowere spatially separated. As a possible cause for the occurrence of epidemic, the problems such as reduced capacity of hospital beds, transferring patients from one department to another, and the lack of room for physical isolation of infected patients with separate toilets have been pointed out.

The epidemic lasted 18 months, with a total of 121 affected patients (30 in 2007) (24.8\%); 70 in 2008 (57.8\%) and 21 in 2009 (17.4\%). In the large percentage (77.7\%) of CDAD, the presence of antibodies to toxin A was laboratory confirmed. By endoscopy and histopathological examination, pseudomembranous colitis was diagnosed in $15.7 \%$ of the patients. In this epidemic, the factors contributing to human infection were elderly age, underlying chronic disease, prior antibiotic therapy and prior hospital admissions. Epidemiologic measures to prevent the spread of infection such as patient cohort isolation, reduced use of antibiotics, strict contact precaution measures, in spite of the lack of real spatial isolation with separate toilets, helped reducing the number of cases from 16 to 20 per year at all clinics to sporadic disease cases only $(1,13,14)$.

Epidemiological Service of the Public Health Center in Požarevac in the second half of 2008 introduced the epidemiological surveillance at several departments in the General Hospital Požarevac (departments of orthopedics, urology, and internal departments) in order to prevent the emergence and spread of darrheal syndrome. This epidemiological supervision included the everyday monitoring and recording the incidence of diarrhea in hospitalized patients (from October 29, 2008 to December 5, 2008). By conducted epidemiological surveillance, based on the clinical parameters of patients with diarrhea without etiologic diagnosis, it was assumed that infectious etiology was present in $30.8 \%$ of patients (1).

In May 2009, after the establishment of a cooperation with the Public Health Institute in Niš and the Reference Laboratory for Anaerobic Infections, during a new outbreak of epidemic of diarrhea, it was confirmed that diarrhea was caused by the bacterium $C$. difficile. In this epidemic, there were 8 affected individuals (six female and two male persons) out of the 350 exposed, without reported lethality.

Table 1. The presence of $C$. difficile in samples taken from the human environment

\begin{tabular}{|c|c|c|c|c|}
\hline \multirow{3}{*}{ Sample } & \multicolumn{3}{|c|}{$\begin{array}{l}\text { № of isolates of } \mathrm{C} \text {. difficile bacterium related } \\
\text { to } \mathrm{A} \text { and } \mathrm{B} \text { toxin production }\end{array}$} & \multirow{3}{*}{$\begin{array}{l}\text { № of samples } \\
n\end{array}$} \\
\hline & $(\mathrm{A}+/ \mathrm{B}+)$ & $(\mathrm{A}-/ \mathrm{B}+)$ & $(\mathrm{A}-/ \mathrm{B}-)$ & \\
\hline & $\mathrm{n}$ & $\mathrm{n}$ & $\mathrm{n}$ & \\
\hline $\begin{array}{l}\text { Soil taken from the ground within the } \\
\text { Clinical Center Niš }\end{array}$ & 1 & 0 & 1 & 30 \\
\hline $\begin{array}{l}\text { Soil taken from the parks at the } \\
\text { territory of the Municipality of Niš }\end{array}$ & 0 & 0 & 0 & 20 \\
\hline Water of the Kutina river & 0 & 0 & 0 & 10 \\
\hline River sand (banks) of the Kutina river & 0 & 0 & 0 & 10 \\
\hline $\begin{array}{l}\text { River sand (banks) of the Kutina river } \\
\text { taken } 5 \text { meters from illegal sewage } \\
\text { outlets }\end{array}$ & 0 & 0 & 1 & 10 \\
\hline $\begin{array}{l}\text { Mud of the Kutina river taken } 5 \text { meters } \\
\text { from illegal sewage outlets }\end{array}$ & 1 & 0 & 1 & 10 \\
\hline Fresh plants & 0 & 0 & 0 & 10 \\
\hline Hospital environment & 0 & 0 & 0 & 50 \\
\hline Environment of private houses & 0 & 0 & 0 & 25 \\
\hline TOTAL & 2 & 0 & 4 & 175 \\
\hline PROPORTION & $1 \%$ & $0 \%$ & $2 \%$ & $100 \%$ \\
\hline
\end{tabular}

All of the affected were above the age of 50 and were immunocompromised with severe underlying conditions; the temperature elevated even up to $39^{\circ} \mathrm{C}$, leukocytosis, fatigue, pains, cramps, and abdominal bloating sensation were the predominant symptoms among the affected. The outbreak ended on September 24, 2009 (1). The architectural lack of spatial isolation of patients with diarrhea, hospital rooms with several beds 
(up to 8), common sanitary facilities with toilets and showers, and insufficient numbers of nurses, contributed to the onset of all the above-mentioned epidemics in different hospitals in Serbia.

The analysis of the stool samples in the NRLA of the Public Health Institute Niš revealed that the epidemics were caused by $C$. difficile producing both toxin $A$ and toxin $\mathrm{B}(\mathrm{A}+\mathrm{B}+)$. Resistance to metronidazole and vancomycin was not established in any of the isolates.

In the period 2005-2010 at the Public Health Institute in Niš, the first study was done about the prevalence of toxigenic and non-toxigenic strains $(1,15$, 16) and C. difficile carrier status (17) in patients and people from the territory of Serbia. The results of the study showed the predominance of strains producing both toxins $(\mathrm{A}+\mathrm{B}+)$, but also the presence of strains that produce toxin $B$ only $(A-B+)$, which requires the use of microbiological diagnostic tests to reveal and confirm both toxins in order to avoid false negative results (16).

In 2014, the first isolates of $C$. difficile were obtainned from 175 environment samples in the research studies that took place in the NRLA (Public Health Institute Niš) (18). In the samples of soil taken from the ground within the Clinical Center Niš, those taken from the parks at the territory of the Municipality of Niš, samples of mud and sand around the illegal sewage systems at the terri-tory of the Municipality of Niška Banja, a small number of bacteria $C$. difficile producing the toxins
$(\mathrm{A}+\mathrm{B}+)$ as well as non-toxigenic isolates (A-B-) were detected (Table 1).

\section{CONCLUSION}

Results of the first epidemiological studies (20052007) of the cases of diarrhea associated with prior antibiotic therapy in hospital patients in different health care facilities in our country, microbiological investigations performed at the Public Health Institute in Niš, as well as the conclusions of public discussions at national conger-sses and expert meetings influenced the general conclusion that there is a justified need for the introduction of microbiological diagnosis of CDAD on a daily basis into the Serbian laboratories. After 2006, most microbiological laboratories throughout Serbia started to apply rapid tests to detect toxins in stool samples, being continually professionally supported by the Reference Laboratory for Anaerobic Infections of the Public Health Institute in Niš. The introduction of laboratory diagnosis of CDAD, which improves etiological diagnosis in many hospital epidemics in health care institutions, can significantly contribute to the development of health care in general in Serbia. 


\section{References}

1. Stojanovic P. ", Role of Clostridium difficile in pathogenesis of the disease in intestinal tract ," Doctoral dissertation, University of Nis, Faculty of Medicine, 2010.

2. Hall IC, Tool E. Intestinal flora in newborn unfants with a description of a new pathogenic anaerobe, Bacillus difficilis. Am J Dis Child 1935; 49:390-402. https://doi.org/10.1001/archpedi.1935.01970020105010

3. Larson HE, Paryy JV, Price AB et al. Undescribed toxin in pseudomembraneus colitis. Br Med J 1977; 1: $1246-8$. https://doi.org/10.1136/bmj.1.6071.1246

4. Hafiz S. Clostridium difficile and its toxins. Department of Microbiology, University of Leeds. (dissertation, PhD); 1974.

5. Blawat F, Chylinski G. Patogenic clostridia in soil and feces of domestic animals in the Gdansk region. Bull Inst Marine Med 1958; 9:117-26.

6. Kim KH, Fekety R, Batts DH, Brown D. Isolation of C.difficile from the environment of contacts of patients with antibiotic-associated colitis. J Infect Dis 1981; 143: 42-50.

https://doi.org/10.1093/infdis/143.1.42

7. Al Saif N, Brazier JS. The distribucion of Clostridium difficile in the environment of South Wales. J Med Microbiol 1996; 45: 133-7. https://doi.org/10.1099/00222615-45-2-133

8. Stojanovic P, Kocic B. Hospital infections in Serbia caused by Clostridium difficile (introductory lecture by invitation). 7th congres of medical mycrobiology MIKROMED. Belgrade, 2010. Proceedings (in extenso) 1-5.

9. Stojanovic P, Kocic B, Miljkovic-Selimovic B et al. Presence of bacteria causes dijarealnog syndrome in hospitalized patients. Preventive medicine days-Nis 2007; Zbornik rezimea: 39- 43.
10. Stojanovic P, Kocic B, Ranđelovic G, Antic S. Clostridium difficile: epidemiology, diagnosis and treatment. Acta Fac Med Naiss. 2006; vol 23: 2. 99-107.

11. Stojanovic P, Kocic B, Ranđelovic G, Stojanovic V. Clostridium difficile: The first isolates in Institute of Public Health-Niš. 5th congres of medical mycrobiology-MIKROMED Belgrade 2006; Proceedings: $57-8$.

12. Stojanovic $\mathrm{P}$, Kocic $B$, Mladenovic-Antic $S$ et al. The importance of alcoholic shock in cultivation of Clostridium difficile from stool specimens. 6th congres of medical microbiology - MIKROMED Belgrade 2008; Proceedings: 93-7.

13. Duric $\mathrm{P}$, Ilic $\mathrm{S}$, Petrovic $\mathrm{V}$ et al. Registered outbreaks of infectious diseases in the AP Vojvodina. In: Infectious Diseases in AP Vojvodina in 2007. Novi Sad: Institute of Public Health of Vojvodina, 2008. p. 142-3.

14. Šeguljev Z, Ilic S, Injac D et al. Nosocomial infections. In: Infectious Diseases in Vojvodina in 2009. Novi Sad: Institute of Public Health of Vojvodina, 2010. p. 83-9

15. Stojanovic P, Kocic B, Stojanovic M et al. Clinical Importance and Representation of Toxigenic and Non-Toxigenic Clostridium difficile Cultivated From Stool Samples of Hospitalized Patients (Article). Braz J Microbiol, (2012), vol. 43 br. 1: 21523.

16. Stojanovic P, Kocic B. Diarrhoea caused by Clostridium difficile in patients with postoperative subhepatic abscess. Vojnosanit Pregl 2008; vol. 65, 3: 249- 54 .

17. Stojanovic P, Stojanovic N, Kocic B et al. Asymptomatic carriers of Clostridium difficile in serbian population (Article). Cent Eur J Med, (2012), vol. 7, 6: 769-74.

18. Stojanovic P. Epidemiological - diagnostic aspect of infections caused by Clostridium difficile. Proceeding of Preventive medicine days/ Dani preventivne medicine 2014: 56-62.(http://www.izjz-nis.org.rs/) 


\title{
Doprinos razvoju medicineu Srbiji: deset godina od uvođenja mikrobiološke dijagnostike Clostridium Difficileu Srbiji
}

\author{
Predrag Stojanović1,2, Branislava Kocić ${ }^{1,2}$, Gorana Dragovac ${ }^{3,4}$, Marina Ranđeloviće, \\ Vukica Pantović2 ${ }^{2}$ Zorica Mitić ${ }^{,}$Kristina Stojanović ${ }^{6}$
}

\author{
${ }^{1}$ Univerzitet u Nišu, Medicinski fakultet, Niš, Srbija \\ 'Institut za javno zdravlje Niš, Niš, Srbija \\ ${ }^{3}$ Univerzitet u Novom Sadu, Medicinski fakultet, Novi Sad, Srbija \\ ${ }^{4}$ Institut za javno zdravlje Vojvodine, Novi Sad, Srbija \\ ${ }^{5}$ Zavod za javno zdravlje Požarevac, Požarevac, Srbija \\ ${ }^{6}$ Oftalmološka ordinacija "Zona Vida" Nǐ̌, Srbija
}

\section{SAŽETAK}

U Srbij su prvi izolati $C$. difficile dobijeni u Institutu za javno zdravlje (IZJZ), Centru za mikrobiologiju Niš, krajem 2005. godine. U Nacionalnoj referentnoj laboratoriji za anaerobne infekcije (NRLA) u IZJZ Niš potvrđeni su toksigeni sojevi, uzročnika prve tri registrovane bolničke epidemije u Srbiji: 2006. godine na Klinici za neurologiju u KC Niš, 2007. godine u Kliničkom centru Vojvodine u Novom Sadu i 2009. godine u opštoj bolnici Požarevca.

Tokom 2014. godine izolovani su prvi sojevi $C$. difficile iz 175 uzoraka čovekove okoline. $\mathrm{U}$ uzorcima zemljišta u krugu Kliničkog centra Niš, parkova Niša, uzorcima mulja i peska oko izvoda divljih kanalizacionih sistema na teritoriji opštine Niška Banja utvrđene su bakterije $C$. difficile koje produkuju toksine $(\mathrm{A}+\mathrm{B}+)$ kao $\mathrm{i}$ netoksigeni izolati (A-B-)

Rezultati prvih epidemioloških ispitivanja u našoj zemlji, utvrđen značaj $C$. difficile $\mathbf{u}$ nastanku dijareja kod hospitalizovanih bolesnika na dužem antibiotskom trentmanu u većem broju zdravstvenih centara, razmatranja potreba službe na stručnim i naučnim sastancima, uslovili su generalni stav da mikrobiološka dijaganostika, odnosno izolacija i identifikacija $C$. difficile i/ili detekcija produkcije toksina ove bakterije, bude deo rutinskog rada mikrobioloških laboratorija u Srbiji.

Ključne reči: C. difficile, Srbija, uzorci okoline 